\title{
Exhalation Valve Device
}

National Cancer Institute

\section{Source}

National Cancer Institute. Exhalation Valve Device. NCI Thesaurus. Code C50247.

A valve designed to allow the escape of exhaled gases from a respirator or respiration system. 